\title{
原著
}

口腔内環境と歯周疾患との関連性に関する研究

とくに混合喠液の Proteolytic activityおよび紘街能について

田 中 正 恕 ${ }^{*}$

\section{3. 混合唾液緩衝能の測定成綪}

\section{i ）各症別の成縝}

各症別, 蛋白質分解能試験成績別で,それぞれの pH6.8４.0に移動するに要した0.1 N Lactic acidの消費量をもって成績としたのであるが，そ

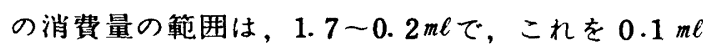
段階で分布度数を表わしてみると，表 9 のとおり になる。

これをみてみると, 各症ともそれぞれの蛋白質 分解能試験成績別に分けると, 現わした度数は相 当広い範囲に汎っているものや，狭い範囲に止ま つているものやいろいろであって，甚だ不規則で まとまりがつかないが, 症別のみでまとめてみる と, 図 3 のような分布曲線が得られた。

健常者の頂点は $0.5 m \ell て ゙$ 䋸衝能の弱い側にあり， 歯槽膿漏患者の頂点は $1.0 \sim 0.8 m \ell て ゙$ 健常者より緩 衝能の強い側にある。歯肉咨患者は度数は少なく て $1.0 \sim 0.6 m \ell$ と幅広くなっている。

これら症別のLactic acid消費量の平均值を求 めてみると, 表10のことくになり, 健常者の平均 值は $0.74 \pm 0.03 m \ell て ゙ ，$ 歯槽膿漏患者のそれは 0.98

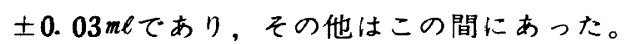

これらの平均値の有意差検定を行ってみると表 $11 の こ ゙ と く に な り ，$ 健常者と歯肉炎患者とでは有 意差が認められなかったが, 健常者および歯肉炎 患者と歯槽膿漏患者とでは強度の有意差が認めら れた。歯槽膿漏患者の各症別間には有意差が認め られなかった。

\section{ii）蛋白算分解能試験成維別の成䋹}

蛋白質分解能試験の成績別に全被㭘者の成績を まとめてみると, その度数分布は表 12 のとおりに

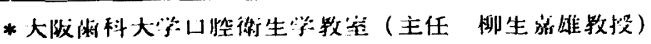

なる。分布曲線は図 4 に亦した。

平均值を求めてみると，表13のとおりで, 強㓌 性者の平均值は $0.73 \pm 0.02$ で, 強陽性者の平均値 は0.97士0.02で，健常者に比らべ強陽性者のほう が緩衝能が強く，その他はこの両者の間にあり， 表13に示したように险性者の強弱間に強度の有意 差が認められ，また陽性者の強弱間も同様である。

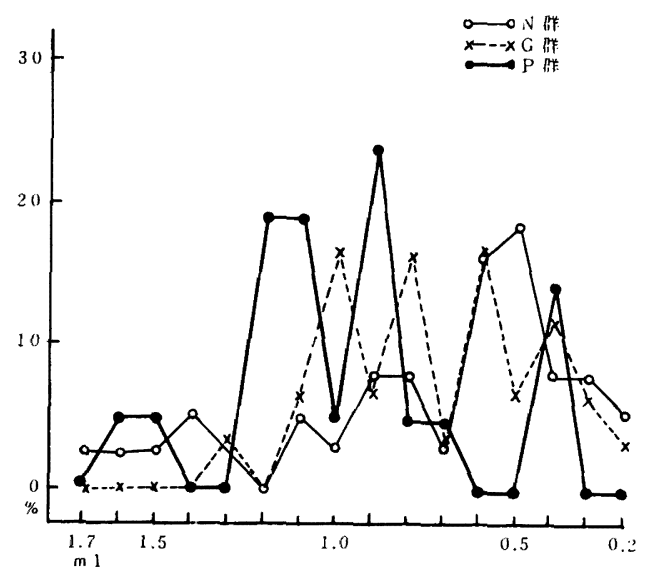

図 3 表 9 の図示

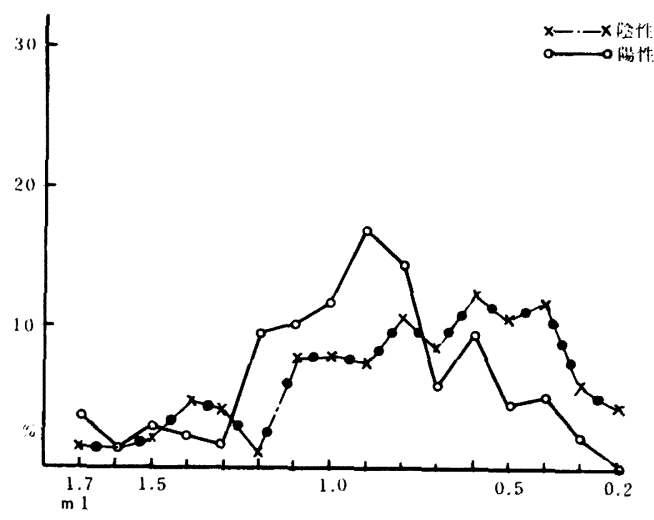

図 4 表12の図示 
裹 9 各症別 Lactic acidの消費量分布度数

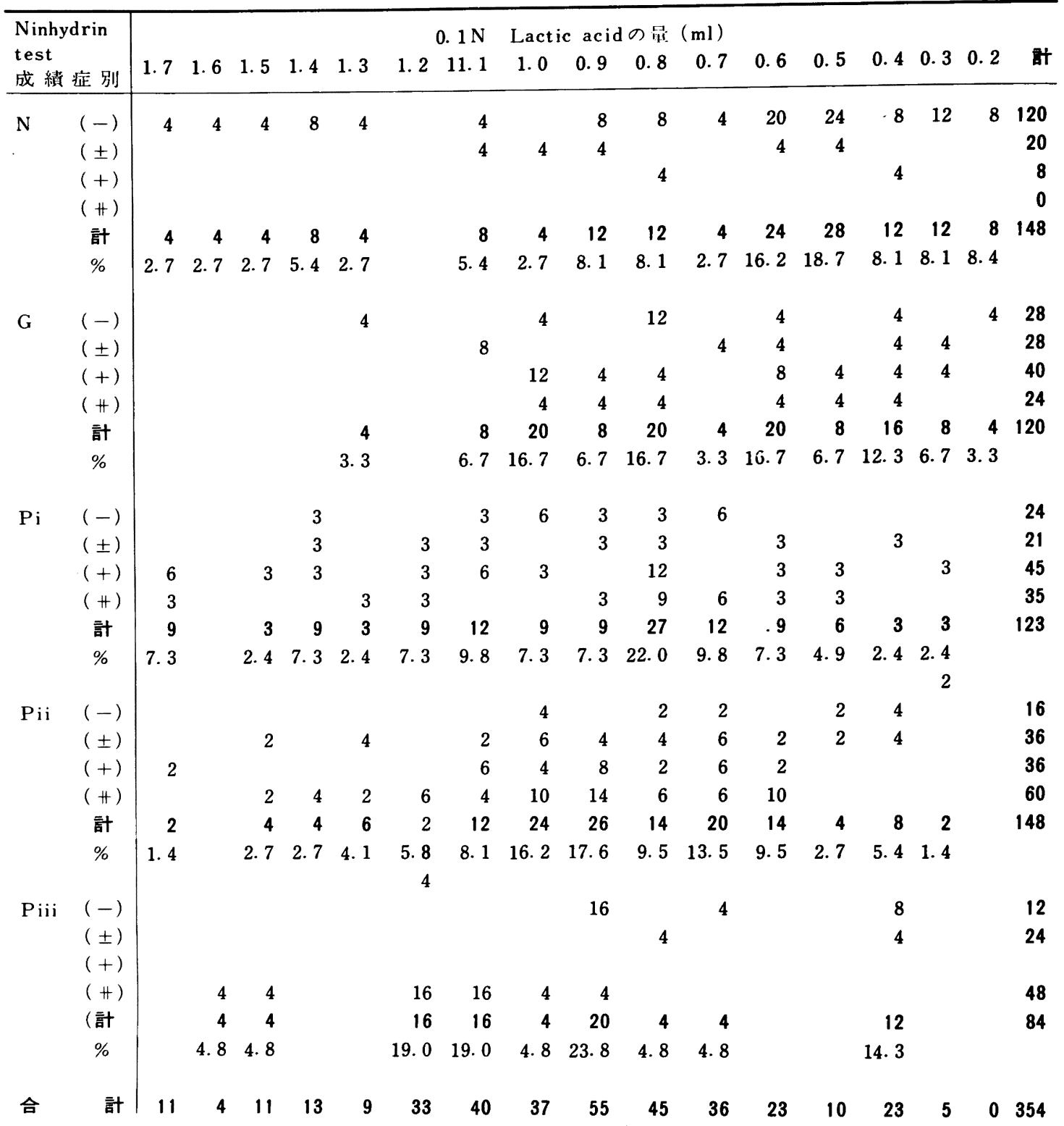

全㓌性と全陽性者間にも強度の有意差が認められ たが, 㓌性弱と陽性弱の間には有意差が認められ なかった。

\section{4. 実験成縤の総括}

以上の成繢をまとめてみると, 混合咞液の蛋白 質分解能すなわちHide powderを用い, Ninhyd- rin testによる成績は個人差があり, 同一症のも のでもいろいろの成績を現わすが，各症別に 1 つ の傾向を示した。

すなわち, 健常者の殆んどは陰性であり, 強度 の雪槽膿漏患者の殆んどは陽性である。要亏るに 歯周疾患のない口腔内環境では，その混合哦液は 㔻白質分解能が無いのが通常であって, 健常者で 
表10 症別0.1 N Lactic acid消費量の平均值

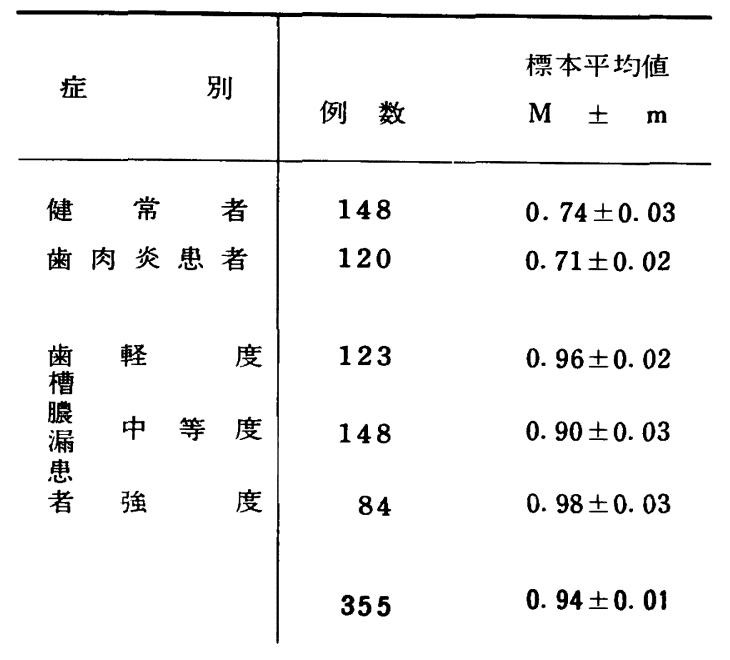

表110.1 N Lactic acid消費量の平均值の比較検定

\begin{tabular}{l|rrcl}
\hline & \multicolumn{1}{|c}{ 例 数 } & $\mathrm{M}$ & $\mathrm{t} \mathrm{s}$ & 有意水準 \\
\hline $\mathrm{N}$ & 148 & 0.74 & & \\
$\mathrm{G}$ & 120 & 0.71 & 0.083 & $\mathrm{P} \mathrm{r}<1.96$ \\
$\mathrm{P}$ & & & & \\
$\mathrm{Pi}$ & 120 & 0.96 & $6.11 * * *$ & $\mathrm{P} \mathrm{r}<3.29$ \\
$\mathrm{Pii}$ & 148 & 0.90 & $3.81 * * *$ & $\mathrm{P} \mathrm{r}>3.29$ \\
$\mathrm{Piii}$ & 84 & 0.98 & $5.71 * * *$ & $\mathrm{P} \mathrm{r}>3.29$ \\
$\mathrm{P}$ & & & & \\
$\mathrm{Pi}$ & 120 & 0.96 & & $\mathrm{P} \mathrm{r}<1.96$ \\
$\mathrm{Pii}$ & 148 & 0.90 & 1.66 & $\mathrm{P} \mathrm{r}<1.96$ \\
$\mathrm{P}$ iii & 84 & 0.98 & 0.55 &
\end{tabular}

表12 Ninhydrin testによる蛋白質分解能試験成績別にみた

$$
0.1 \mathrm{~N} \text { Lactic acid消費量の分布度数 } n=623
$$

\begin{tabular}{|c|c|c|c|c|c|c|c|c|}
\hline \multirow{2}{*}{$\begin{array}{l}\text { Lactic acid } \\
\text { 消費量 } m \ell\end{array}$} & \multicolumn{2}{|c|}{ 㓌 } & \multicolumn{2}{|c|}{ 性 } & \multicolumn{3}{|c|}{ 陽 } & \multirow[b]{2}{*}{$\%$} \\
\hline & $(-)$ & $( \pm)$ & 計 & $\%$ & $(+)$ & $(H)$ & 計 & \\
\hline $1 \cdot 7$ & 4 & & 4 & 1.3 & 8 & 3 & 11 & 3. 5 \\
\hline 1.6 & 4 & & 4 & 1. 3 & & 4 & 4 & 1. 3 \\
\hline 1.5 & 4 & 2 & 6 & 2. 0 & 3 & 6 & 9 & 2. 8 \\
\hline 1.4 & 11 & 3 & 14 & 4. 6 & 3 & 4 & 7 & 2. 2 \\
\hline $1 \cdot 3$ & 4 & 8 & 12 & 3. 9 & & 5 & 5 & 1. 6 \\
\hline $1 \cdot 2$ & & 3 & 3 & 1. 0 & 9 & 21 & 30 & 9.4 \\
\hline $1 \cdot 1$ & 7 & 17 & 24 & 7.9 & 12 & 20 & 32 & 10. 1 \\
\hline 1.0 & 14 & 10 & 24 & 7. 9 & 19 & 18 & 37 & 11.6 \\
\hline 0.9 & 11 & 11 & 22 & 7.2 & 28 & 25 & 53 & 16. 7 \\
\hline 0.8 & 25 & 7 & 32 & 10.5 & 26 & 19 & 45 & 14. 2 \\
\hline 0.7 & 16 & 10 & 26 & 8. 5 & 6 & 12 & 18 & 5.7 \\
\hline 0.6 & 24 & 13 & 37 & 12.1 & 13 & 17 & 30 & 9.4 \\
\hline 0.5 & 26 & 6 & 32 & 10.5 & 7 & 7 & 14 & 4. 4 \\
\hline 0.4 & 24 & 11 & 35 & 11.5 & 12 & 4 & 16 & 5. 0 \\
\hline 0.3 & 14 & 4 & 18 & 5. 9 & 7 & & 7 & 2.2 \\
\hline 0.2 & 12 & & 12 & 4.0 & & & & 0 \\
\hline 計 & 200 & 105 & 305 & & 153 & 165 & 318 & \\
\hline
\end{tabular}


表13 Ninhydrin testによる蛋白質分解能試験成績別にみた

Lactic acid 消費量の平均值

\begin{tabular}{|c|c|c|c|c|c|c|c|c|}
\hline \multicolumn{2}{|c|}{$\begin{array}{r}\text { Ninhydrin } \\
\text { test 成績 }\end{array}$} & \multirow{2}{*}{$\frac{\text { 例 数 }}{200}$} & \multicolumn{3}{|c|}{ 慓 本 平均 值 } & \multirow[t]{2}{*}{$m \ell$} & \multirow{2}{*}{$\frac{\mathrm{t} \mathrm{s}}{3.33 * * *}$} & \multirow{2}{*}{$\frac{\text { 有意水準 }}{\operatorname{Pr}>3.29}$} \\
\hline 陰 & $(-)$ & & 0.73 & \pm & 0.02 & & & \\
\hline & $( \pm)$ & 105 & 0.85 & \pm & 0.03 & & & \\
\hline 性 & 計 & 305 & 0.800 & \pm & 0.02 & & & \\
\hline \multirow[t]{2}{*}{ 陽 } & $(+)$ & 153 & 0.87 & \pm & 0.03 & & \multirow[t]{3}{*}{$2.78 *$} & \multirow[t]{3}{*}{$\operatorname{Pr}>2.58 *$} \\
\hline & $(\#)$ & 165 & 0.90 & \pm & 0.02 & & & \\
\hline 性 & 計 & 318 & 0.90 & \pm & 0.02 & & & \\
\hline 陰 & 性 & 305 & 0.8 & & & & \multirow{3}{*}{$3.57 \approx *$} & \multirow{3}{*}{$\operatorname{Pr}>3.29$} \\
\hline \multirow[t]{4}{*}{ 陽 } & 性 & 318 & 0.9 & & & & & \\
\hline & $( \pm)$ & 105 & 0.85 & & & & & \\
\hline & $(+)$ & 153 & 0.87 & & & & 0.476 & $\operatorname{Pr}>1.96$ \\
\hline & $(\#)$ & 165 & 0.97 & & & & 3. 333 & $\operatorname{Pr}>1.96$ \\
\hline
\end{tabular}

陽性を示すものは将来歯周疾患を発症する可能性 があるといえると思う。

歯周疾患のある口腔内環境での混合哑液は陽性 反応を示すものが增し, 強度の歯周疾患すなわち 雬槽膿漏症の強度のものに䍜患している場合は殆 んどが陽性反応を示す。特例として僅かに隍性の ものがあるにすぎな。

健常者とこの強度の歯槽膿漏患者の中間に属す る歯周疾患患者すな⿰ち歯肉炎, 歯槽膿漏の軽度 のものおよび中等度のものに罹患している口腔内 環境のものは, 各様の反応を呈し, 健常者に比ら へ陽性反応のものがはるかに多く，またその症状 の進行するにつれ，陽性反応を示すものが增して くる傾向があるが，㓌性反応を呈するものとの間 に有意差を認められるほどの差は見出し得なか つた。

これらのうちこの歯周炎患者を治療，すなわち 軽度のものは歯石除去を行い, 強度のものは盲䔬 搔把を行ったのであるが, 治療経過中の蛋白質分 解能の変動を調らへてみると, 歯肉炎患者の全部 は術前強陽性であったものが，術後一過性に陽性 度は高まるが漸次その反応は弱まり，1 ケ月後に
は陰性となる。

このケースのものは予後は非常に良好で完全治 痛をする。このケースに属するものは尿中ウロビ リン体, 蛋白質, 糖の反応も陰性で, 単なる局所 的原因で歯肉炎に罹患したものと思われる。

歯槽膿漏患者の大半は術前強陽性であったもの が, 術後一過性にその反応が弱くなるが, 約10日 間もするとまたもとの反応に戻ってくる。これら の尿検では糖や蛋白を証明し, ウロビリン体も多 少認められた。このケースのものは歯槽膿漏の成 因は単なる局所的原因のみならず全身的原因にも 由来していると思われ，盲举搔把により一時的に 局所が軽快するので, 蛋白質分解能反応が弱まる が,すぐもとの反応を示すようになる。尿中に糖 や蛋白質の反応を示すのと一連の因果関係があり， 口腔内環境と全身症状との関連性があるように思 われる。所謂歯槽膿漏症に罹患し易い口胿内環境 のものといえるのではないか, 予後も思わしくな いものが多い。

特異な例として術後か之って蛋白質分解能反応 が強くなり，そのまま1ケ月の試験期間持続する ものがある。このケースのものも尿中に異常物質 
が認められた。

この蛋白質分解能成績と混合唾液の緩衝能とは 関連性があり, 症状とは関係なく, どの症状のも のでも; 陰性反応を示したものより, 陽性反応を 示したもののほうが, 平均では緩衝能が強く, 同 じ陰性あるいは陽性内でもその反応の強弱によっ ても差があり, 強陰性よりも弱陰性のほうが緩衝 能は強く，また弱陽性より強陽性のほうが強力で ある。ただ弱陽性と弱㓌性間には差がなかった。

この成績からみると, 混合咞液の緩衝能と, 蛋 白質分解能との間に判然とした関連が認められる のである。

蛋白質分解能成績と関係なく，単に症状別で混 合呏液緩衝能を調らへててると，その平均值では， 健常者とそれに近いものすなわち歯肉炎患者との 間には差がなく，歯䄚膿漏患者に比らへて弱く， 歯槽膿漏患者のほうが強い。歯槽膿漏患者の各症 間には差がなかった。

以上の成績からみて歯周炎に罹患している口腔 内環境では、混合噍液の蛋白質分解能はその症状 が増覀するにつれ陽性者が增してくる。すなわち 歯周炎と混合血液の蛋白質分解能との間には一連 の関連性があると思われ，この分解能の成績と混 合啎液緩衝能とも関連性がある。すなわち蛋白質 分解能の高い唕液は緩衝能は強力である。従って 蛋白質分解能の陽性を示すものの多い歯槽膿漏患 者はその他のものより混合唾液緩衝能は強力で ある。

㐘周炎治療経過において, 蛋白質分解能が陰性 に変動するものは, 単純性症状で, その治療経過 も良好であるが, 陽性を続けるものは, 局所的だ けでなく，他蔵器疾患の関連性あるものと思われ， 治療経過も思わしくなく，歯槽膿漏に罹患し易い 口胿内環境にあるものといえると思われる。

\section{III. 考按}

歯の硬組織疾患の1つである龋蝕症に対しては 古くからHadley \& Bunting(1933) 14), Hadley (1933) 15)らをはじめ Fosdickら (1937) 16), Snyder (1940)17), Rickles (1952)18), (1953) 19), Wach (1943) 20) らがCaries Susceptibility あ
るいは, Caries activity なる語を用いてその 試験方法をいろいろと発表して来ている。Appleton （1950）21）は彼の著書に口腔内疾患とくに鮞蜆に 関してはその破壊因子と抵抗因子との两因子のつ クあいが保っている場合とそうでない場合との両 面からみて, 病状の進行度が決定されるはづであ るから，常に破壊因子が抵抗因子よりその力が大 であるときは，急速にしかも重症として進行中の 疾患が現われている証拠であることを述へている。 前述のCaries activity testなどを考え出した人 らも，大方この理論に立脚し，或は破壊因子を， Lactobacillus acidophilusだと考えた人は16) そ の菌数を数えることによって破壊因子大なる条件 の1つとみなしており，醇酸が主因と考える人た ち15１9）はその酸量や, 醸酸能力をしらへること によって破壊因子大とみなしている。このような 理論にもとついてロ腔内 2 大疾患の他の 1 つであ る歯槽膿漏症を考えてみるとき，同じようなこと が言えるはづであるし，またその破壊因子を何で あるかときめてかかることによって自ら，それを 主にした環境検查試験が生れてくるはづである。

残念乍ら今日までに歯周炎に関する限り,この 疾病のSusceptibilityやactivityについての考之 方をまとめたものは数少く，真下ら（1962）12)22), 細川（1960）23）をのぞいては他に報告をみない。 その反面Schultz-Haudt \& Scherp (1955)24) やRoth and Meyers(1956) 8), Roth(1957) 7) およびThonard and Scherp (1957)25)らによる と，いづれもロ腔内に，なかんつく歯肉虽内から 多数の微生物を分離し，とくに歯肉に炎症を伴う 場合にはそれからの菌の大部分に蛋白質溶解酵素 を産出する能力を有することを報じ，なおそれら の多くは, CollagenやHide powderを溶解する ことを報告している。

また歯槽膿漏の症状からみて病巣内には数多く の蛋白質溶解菌が捿息していることが想像出来る のである。したがって雬周炎の原因が何であるか はなかなか解決の困難な問題であるが, その病気 が進行して行く途上あるいは，もともと局所が何 かの影響によって抵抗減弱を来したときに直接破 壊的に働く因子であるところの蛋白質溶解酵素が 
多いか少いかは何といってもその疾病の活性度と 密接な関係があるといわねばならない。だから， それらの菌が混入している人の混合睡液がどのよ うな程度にHide powder やCollagenに対して破 壊的に動いているかをしらべることこそ必要なこ とであり，また歯周炎などの軟組織疾患の活動性 をしらべる理にかなった方法と言はねばならない。

Schultz-Haudt and Scherp（1955）24）は歯 肉から採取した材料を混合培養しその培養物が, Collagenolytic activityをもっているものは， 慢性歯肉炎患者（19例中13例)，臨床的正常な歯肉 からは21例中 3 例しかなかったと報じている。Roth \& Meyers (1956) 8) は Hide powder を plate medium に応用して，人のロから，60例中57例に Proteolysis を営む微生物の分離に成功したと報 じかつ細菌学的見地からいろいろ詳細な検查をし ている。その他の先人の成績をみても大体歯肉炎 や歯槽膿漏の歯肉縁からは相当率のProteolytic organismsを分離している。このような成績から みて真下ら(1962) 12) は最初にPeriodontal disease activity test と云う語を提唱するにあたり， そのactivityの本態に唾液中のProteolytic activityをもって検討し，ついで細川（1960）23）も Azocoll powder を自製してその分解程度をしら べそれによって，歯周炎を有する人の唾液とそう でない人の唾液との間に相当なひらきをもって分 解能力の差を示している。

私はこれらの先人の成績からみてHide powder を分解する程度をもっと詳細にしかも生化学的な, Analysisを行うために，その分解能をNinhydrin testによってしらへ，Electrophotometerによっ てその正確度を期待したのである。細川（1960）23) は唾液採取を起床時直後に行っており，私は実験 方法の項で述へたように，昼食前に採取している。 細川の成績はAzocoll powder の分解すなわち反 応時間が大一ん短く, 蛋白質分解能が高度で, 睡 眠中に增殖し充分活力をもった微生物を全部集め て反応をみていることになるから，有用且便利な テスト法として推鹰出来るかもしれないが，それ だけに他条件に支配される心配がないでもない。 例えば実験時期が冬と夏の相違或は食餌の何かの
因子による酵素活性賦活作用などを見逃がすわけ にはゆかない。そこで私は食餌の制限をもうけ， かつ朝食後すなわち自然に機械的作用と相俟って 口腔内微生物数の激減する時期に, 更に菌磨剤と 歯刷子を利用して徹底的に口内を清掃させ，それ でなお且口内の盲歯間乳頭の深部に残存する 所謂口腔内常在微生物の残存したものが再び繁殖 し始めて来た頃をねらって唾液採取をしたのであ る。しかもそれらの弱能力であるはずの微生物を 混入した唾液に直接 Hide powder 作用させて から培盖することにより，唾液と Hide powder だけを栄盖に楼息する微生物がどの程度 Hide powder を分解するかをしらべ得たのである。そ

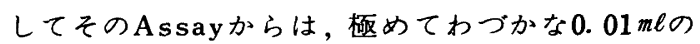
反応物をとり出してNinhydrinでしらべたために 相当の正確度が期待出来るものと考えている。

成績の総括的なものを細川のAzocoll test と 比較すると, Azocoll test 陰性者が健常者は 75 $\%$ ，歯肉炎患者は $0 \%$ ，歯槽膿漏患者は $40 \%$ とな っておるのに反し，私の成績ではむしろ，健常者 が極端に多くて95\%，G群は47\%，P群は31\%（Pi: 37\%, Pii: 35\%, Piii: 14\%) となっており，反 对に陽性者を比較するとAzocoll test では，N 群が $25 \% ， \mathrm{G}$ 群が60\% となるのに反して私のNinhydrin test による蛋白質分解能試験ではN 群は わづか $5 \%, \mathrm{G}$ 群が約半数をしめ $53 \% ， \mathrm{P}$ 群が最 も多く69\%（Pi: 63\%，Pii: 65\%，Piii: 86\%）を しめしている。このように Azocoll test ではG 群の方が P 群より陽性者が多いのに反し, Ninh. ydrin testの方では G 群より P 群の方が高率を示 している。これは唾液の採取要領に差があるもの と考えられ, 前者は起床時直後という人間にとっ ては一番口腔内細菌数の多い, 繁殖度最高の時期 の唾液であるから $\mathrm{G}$ 群などは特に $\mathrm{P}$ 群にくらべて 活力の高い微生物が症状に応じて多く存在してい ることがうなづけるのであるが, 後者に於ては歯 口の充分な清掃を行った後, 口腔内で微生物が Logarismic Phase に入った頃の唾液を採取し ており，なおNinhydrin testに出来るだけ支障を 来さないように食餌の制限をもうけた結果, 正常 な口内条件をもつ人は食後の歯口清掃の影響をう 
けて殆ど微生物数も少なく，活性も低調な状態で あるように思われる。その反面盲整の深い人や進 行中の症状の多い人は歯口清掃の実があがらずむ しろ局所が刺戟によって㑢出物などを多く分泌し たため，本来の哑液だけでなしに，浸出物が栄着 の一部を司っているようにも思われる。いづれに しても盲検值を差引いた価によって，陰，陽性を 判定しているわけであるから, 症状の軽重, 浸出物 の多少などから直接に受ける影響が成績にあらわ れているのでAzocoll testより正確で歯周炎活性 の探索には，より信頼すべきtestとしてNinhydrin testを提唱することが出来る。

次にこれの臨床的応用の成績であるが， 1 回で 全顎施術及び処置の出来るケースがなかなか見当 らないので症例はわづかであるが大体に於て，術 前との成績からみて，3つの型に睡液の蛋白質分 解能が分けられるようである。すなわち

a . 術後急激に上昇曲線すなわち反応が強まり,

4〜5 日で下降するが, 徐々にそのまま下降曲 線を描いて遂には30日頃になると（一）になっ てしまうもの

b. 術後急激に下降し反応が弱まってしまうが, $2 \sim 3$ 日頃から再び上昇曲線を示して遂には術 前と同じ积度の反応能力の線までもどってしま うもの

c . 術前よりもだんだんと上昇し下降する傾向は 一度も示さないで，遂には術前よりも上年した 部位でとどまってしまうもの。

以上の 3 つの型であるが，a．に属するものは 歯肉炎系のものが多く，しかも尿中に何の異常成 分も認められず，臨床的健常を示していた人たち の成績に於てみられたが，b．および c .に属す るものは尿中に異常成分が大なり小なり認められ たものに多い。このような事から見ると口腔内に ひそむ蛋白質分解能を有する微生物の消長も単に 局所の手術などによる機械的な方法によって案外 簡単に影響をうけてしまうようなものがある反面， なかなか敏感にその影響をうけられないで，切角 の手術も効を奏せずもとの状態にもどってしまう ものがあることを知放れる。しかも後者のもの には尿中に異常物質を多く認められる例からみて，
局所の蛋白質分解能を有する微生物の消長すら全 身の諸要因に大きく影響されているもののようで ある。

この成績については他に文献がみあたらないの で比較できない。

以上のことからして, 混合㫫液蛋白質分解能を Ninhydrinによってtestすることによって，陽性 反応を示した場合は㐘周炎疾患に罹患するか战い はその進行性があると見做すことができ，とくに 強陽性の場合はなお増覀症状をとるものと判定で きるのではないか。隍性の場合は健常であるか， あるいは菊周炎疾患に罹患していても，その進行 性は弱いものと判定することができる。

私はなおこの成績を裏付けるために, 混合咞液 の緩衝性をしらべたのであるが，形液の緩衝能に ついてはCaries との関連性については先人の業 績がある。口腔内混合唾液中には酸産生能とalkali 産生能とが常に働き, 混合咞液の固有 $\mathrm{p} \mathrm{H}$ は常に 動摇しているのであるが、これを緩衝する作用が あるとして, Marshall(1915) 26) は1/200N HCl で，桸釈した唎液を滴定し, Rea \& Clegg(1948) 27)や Turner, Scribra \& Bell（1954）28など は0.001N HClで, Sullivan \& Storvick(1950) 29)らは0.01N HCl で滴定して, 標示薬を用いて その成績を判定している。そして緩衝能の大なる ものは㽪蝕活性は除性であるといっているのであ る。またLactic acidを用いて娭定したものに， Muracciole（1955）30)があり, 彼は榴示薬を用 いたのであるが, Dreizen, Mann, Cline \& Spies（1946）13)らは0.1N Lactic acidを用い て滴定し，その都度 $\mathrm{pH}$ を測定しつつ， $\mathrm{pH} 4$ に 下降するまでの量を表示する方法を発表している。 私は実験に当りこの Dreizen らの方法が最も 正確であるので採用した。

これらの人々はそれぞれの方法で実験例につい て混合咞液の緩衝能を测定し, 酯蝕と関係がある

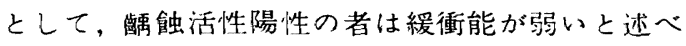
ているのである。また寺田（1941）31)は妊婦の混 合咞液について測定し, 妊張期および授乳期は緩 衝能は弱いと述へ，柳生（1959）32）はこれを詳細 に調らへ，妊婦の混合呏液緩衝能は弱くなるとと 
もに妊張月の差が判然と現われるといい，藤本 （1960）3）は歯槽膿漏患者の緩衝能は強いと述べ ている。

これらの人々は個人差はあるが平均值ではその 傾向を表現し得るといい, Reaら（1948）27）も測 定値に変動はあるが，個体毎に個有の值を決定す ることができるとしている。

このように混合哑液の緩衝能の強弱が, 贎蝕発 生と関係を持ち, 藤本 (1960)3) の述べているご とく歯槽膿漏患者としからさる者との間にも差異 が認められるのである。

Caries activity test にこの Dreizen らの緩 衝能測定法が用いられているのであるが，歯槽膿 漏のactivityについては, 藤本 (1960) 33) が述べ た以外この緩衝能についてはあまり述べられてい ない。私はこれを確めるために実験を行ったので あるが, 矢張り歯槽膿漏患者は健常者に比らべ混 合哑液の緩衝能は強いという成績を得たのである。

そこで先の蛋白質分解能試験の成績との関連性 について調らべてみたところ，そのtest陰性の場 合は緩衝能は弱く, 陽性の場合は緩衝能は強いこ とが確められた。すなわち蛋白質分解能試験成績 との関連性があることがわかった。

すなわち混合哑液の緩衝能の強弱の機転の $1 つ$ に混合呼液の蛋白質分解能の強弱が挙げられるの ではないだろうか。

そこで歯槽膿漏症の混合唾液の一般的性状とし て, 健常者に比らべ蛋白質分解能および緩衝能が 強いということがいえるとともに，この環境を知 ることによって，歯周炎の活性度をtestすること ができると思う。

\section{IV. 結論}

1.人の混合嗝液と Hide powderとを混合して 培養し, Ninhydrin testを応用して,その 蛋白質分解能も知る方法を考案した。

2. 実験に使用した噃液は従来の起床時採取法の 原則に従わず，特定の条件を設けて昼食前に 採取する方法を考案した。

3. 蛋白質分解能をNinhydrinによってtestする 成績の判定基準を明らかにした。
4. 歯周炎患者の哑液と，健常人唾液との間に明 らかに, 蛋白質分解能の差が認められ, 症状 に正比例し雪周炎疾患の場合は蛋白質分解能 が強いことが判明したので，歯周炎活性度試 験の 1 つとして役立つ方法であると信ずる。

5. 臨床的に応用することにより，歯周炎の病巣 に施術した歯石除去手術や盲辁搔把手術の前 後に哑液の蛋白質分解能をtestすると次の 3 つの型があることがわかった。

a. 術後やや反応が高まるが， 4 5 日頃か ら弱まり，除々に下降曲線を示して30日頃 には陰性に移行するもの

b. 術後から急に減弱し 3〜4日で再び上昇 して結果は30日頃，術前と同じレベルまで もどってしまうもの

c．不規則でむしろ術前より上昇してしまう もの

以上の 3 型で a .は尿中に異常成分を認めら れず，b．およびc。は殆ど全例に尿中に異 常物質が検出出来だ。

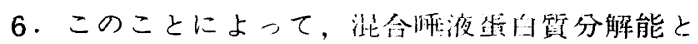
他藏器異常との間に関連性があるのでないか と思う。また臨快に応用することによって， 術後の経渦の予娞の判定に役立つのではない かと思う。

7.また混合形液緩衝能とも関尰性を持ち, 蛋白 質分解能の強い啝液は緩衝能も強く, 歯周炎 とくに歯槽膿漏患者の緩衝能は強い。

稿を終るに臨み終始御指導を忝うした柳生嘉雄教 授と御助力いただいた真下彰助教授に深甚の敬意 と謝意を表します。

\section{引用 女 献}

1. Forsher, B. K., Paulsen, A. G., Hess, W. C: J. Dent. Res., 33, 444, 1954.

2. 大橋良昭：歯界展望, 12(6), 233, 1955.

3 . 藤本治国：歯科医学, $22(7), 2624,1959$.

4. 川上進也：日本口腔科学会, 7(4), 532, 1958.

5.川上進也：日本口腔科学会, 7(4), 518, 1958.

6 . 渡辺義房：歯科医学, $24(2), 348,1961$.

7. Roth, G. D.: Oral Surg., Oral Med., 
Oral Path., 10, 1105, 1957.

8. Roth, G. D. and Meyers, H. I. : ibid., 9, 1172, 1956.

9. Schatz, A, et al: Proc. Penn. Acad. Seience, 28, 44, 1954.

10. 大西正男: 歯科学雑誌, 6, 273, 1949.

11. Schklair, J. L., et al: Int, Assoc, De Dent. Res., Reprinted Abstract, 116, March, 1956.

12. 真下 彰, 他：口腔衛生学会雑誌, 12(3,4) 158, 1962.

13. Dreizen, S., Mann, A. W., Cline. J.K., \& Spies, T.D.: J. Dent. Res., 25, $213,1946$.

14. Hadley, F. P. \& Bunting, R.W.: J. Dent Res., 13, 198, 1933.

15. Hadley, F. P.: J. Dent. Res., 13, $415,1933$.

16. Fosdick, L. S., et al: J.A. D. A., 24, 1275, 1937.

17. Snyder, M. L.: J. Dent. Res., 19, $349,1940$.

18. Rickles, N.H.: J. Dent. Res., 31, 467, 1952.

19. Rickles, N.H.: J. Dent. Res., 32 .
$3,1953$.

20. Wach, E.C. et al. : J. Dent. Res., $22,415,1943$.

21. Appleton, J. L. T. : Bacterial Infection in dental Practice, 462, 1950.

22. 真下 彰, 他：口腔衛生学会隺誌，12(1)，45, 1962.

23. 細川哲良, : 料科医学, 23(5), 1446, 1960.

24. Schultz-Haudt, SD. \& Scherp, H, W. : Proc. Soc. exp. Biol. Med., 89(4), 697, 1955.

25. Thonard, J. C. \& Scherp, H, W.: Proc, Soc, exp. Biol. Med., 96, 165, 1957.

26. Marchall, J. A.: Amer. J. Physiol., $36,260,1915$.

27. Rea, J. \& Clegg, C. T.: J. Dent, Res., 28, 589, 1948.

28. Turner, N., Scribra J.H. \& Bell, J. T. : ibid., 33, 56, 1948.

29. Sullivan, J. H. \& Storvick, C. A.: ibid. 29. 165, 1950.

30. Muracciole, J. C.: ibid. 29. 387. 1955.

31. 尔由正一：口腔病学会雉誌, 15(2), 81, 1941.

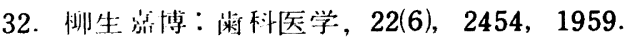

33. 淡本治国：同誌，22(7)，2624，1959. 


\title{
STUDIES ON THE RELATIONSHIP BETWEEN \\ THE ENVIRNOMENT IN ORAL CAVITY AND \\ THE PERIODONTAL DISEASES, ESPECIALLY \\ ON THE SALIVARY PROTEOLYTIC ACTIVITY AND THE BUFFER CAPACITY
}

\author{
B Y \\ Masatada TANAKA \\ Department of Dental Health, Osaka Dental College \\ (Senior Prof.: Y. Yagiu)
}

One of the causative agents the periodontal diseases could be induced sometimes by the changes of circumstances in oral cavity, and it might be vice versa, so many investigators have already informed on this sort of study. While biochemical studies relating to this matter are being active in these days, subsequently, it is reported that the $\mathrm{pH}$ of saliva or salivary ammonium amount are closely related to the periodontal diseases.

On the dental caries which is another one of the 2 largest diseases in oral cavity, the studies on the dental caries activity have been briskly undertaken together with the investigations for the disintegrative mechanisms and the resistant factors, besides, it could be found few works on the periodontal disease activity.

The author just then interested in this problem on the "Periodontal disease activity", of which term had been proposed by Mashimo et al (1962), and the salivas of periodontal diseases' patients has been examined bacteriologically and biochemically. Consequently, it was observed that the symptomatic degree of periodontal disease closely related to the activity of proteolytic enzyms come from the oral microorganisms indigenous to saliva, moreover, this fact was verified by means of the statistical observation.

The results could be summed up as follows:

1. The testing procedures for the proteolytic activity of human contaminated saliva was devised due to employing the hide powder for substrate and measuring the results by ninhydrin test. The experimental salivas were collected with particular terms at just before lunch, of which procedures were not followed in the former steps.

2. It could be recognized that there were distinctly discrepancies between the $s a$ livas of normal controls and of the periodontal diseases, and that the degree of proteolytic acitivity was directly proportional to the symptomatic status of periodontal disease.

3. According to the clinical experiments employed this technique, the salivary 
proteolytic activities were classified to 3 different types as follows:

A) After treatment, the activity increased for 4 to 5 days, gradually decreased after that, and it became negative by the 30 th day.

B) After treatment, it rapidly decreased for 3 to 4 days, increased again and was restored up to the former level.

C) This type showed irregular curve and rather increase after operation.

All cases in A-group checked no abnormal components in the urine, $B$ and C-groups showed various abnormal components in the urine.

4. It was observed the relationship of this activity with the salivary buffer capacity, namely, the saliva of the high proteolytic activity demonstrated large buffer capacity, generally the pyorrheas' saliva showed the large capacity.

Judging from these results, it could be trusted that ex amining the proteolytic activity in saliva is useful as one of the periodontal disease activity tests. Furthermore, it might be imagined that this procedure is helpful for learning the progress and prog. nosis after operation for the periodontal diseases, which related with the systemic conditions, especially, with another organic anomalism. 